\title{
Perlindungan Hukum Whistleblower dan Justice Collaborator dalam Upaya Penanggulangan Organized Crime di Indonesia
}

\author{
Lilik Mulyadi ${ }^{34}$
}

\begin{abstract}
Abstrak
Tulisan ini mengkaji lebih detail model ideal perlindungan hukum Whistleblower dan Justice Collaborator dalam upaya penanggulangan organized crime di Indonesia untuk masa yang akan datang (ius constituendum). Model ideal perlindungan hukum bagi Whistleblower dan Justice Collaborator ini harus berorientasi kepada model hak-hak prosedural, partisipasi langsung, atau aktif. Model ideal ini juga berbentuk model pelayanan atau model partisipasi tidak langsung atau model pasif (the service model), model persuasif atau partisipasi, model perlindungan komprehensif, model penjatuhan pidana bersyarat dan model perlindungan melalui teleconference.
\end{abstract}

Kata Kunci: justice collabolator, perlindungan hukum, organized crime, whistleblower, hakhak prosedural.

\section{Legal Protection of Whistleblower and Justice Collaborator to Eradicate Organized Crime in Indonesia}

\begin{abstract}
This paper examines the ideal model of legal protection of Whistleblower and Justice Collaborator to eradicate organized crime in the future Indonesia (ius constituendum). The proposed ideal models shall refer to procedural rights model, direct or active particiption model. The other ideal models are: services model; persuasive or participatory model; comperhesive protection model; criminal punishment model; and teleconference based model
\end{abstract}

Keywords: justice collaborator, legal protections, organized crime, whistleblower, procedural rights.

\section{A. Pendahuluan}

Secara terminologi, whistleblower dan justice collaborator diartikan kedalam berbagai pengertian. ${ }^{1}$ Pada perkembangan terakhir, Mahkamah Agung melalui Surat

34 Ketua Pengadilan Negeri/Perikanan Klas 1A Khusus Jakarta Utara, Jl. Laksmana R. E. Martadinata No. 4 Jakarta Utara, lilikmulyadi@yahoo.com, S.H., M.H. (Universitas Udayana), Dr. (Universitas Padjadjaran).

1 Whistleblower diartikan sebagai saksi pelapor. Whistleblower dan justice collaborator diartikan sebagai "peniup peluit", ada juga menyebutnya sebagai "saksi pelapor", "pengadu", "pembocor rahasia", "saksi pelaku yang bekerja sama", "pemukul kentongan", "saksi mahkota", "cooperative whistleblower", "participant whistleblower", "collaborator with justice", "supergrasses", "pentiti"/"pentito"/"callaboratore della giustizia", atau bahkan "pengungkap fakta". 
Lilik Mulyadi: Perlindungan Hukum Whistleblower dan Justice Collaborator dalam Upaya Penanggulangan Organized Crime di Indonesia

Edaran Mahkamah Agung RI Nomor 4 Tahun 2011 tentang Perlakuan bagi Pelapor Tindak Pidana dan Saksi Pelaku yang Bekerjasama di dalam Perkara Tindak Pidana Tertentu, menyebutkan pelapor tindak pidana adalah orang yang mengetahui dan melaporkan tindak pidana tertentu dan bukan bagian dari pelaku kejahatan yang dilaporkannya. Seorang pelaku yang bekerja sama (justice collaborator) merupakan salah satu pelaku tindak pidana tertentu, mengakui kejahatan yang dilakukannya, bukan pelaku utama dalam kejahatan tersebut serta memberikan keterangan sebagai saksi di dalam proses peradilan.

Berikutnya, whistleblower berkembang di berbagai negara baik negara Anglo Saxon, Eropa Kontinental maupun negara Quasi Anglo Saxon dan Eropa Kontinental, antara lain Amerika Serikat melalui Whistleblower Act 1989 yang melindungi whistleblower dari pemecatan, penurunan pangkat, pemberhentian sementara, ancaman, gangguan dan tindakan diskriminasi; Afrika Selatan melalui Pasal 3 Protected Disclosures Act Nomor 26 Tahun 2000 yang memberi perlindungan bagi whistleblower dari occupational detriment atau kerugian yang berhubungan dengan jabatan atau pekerjaan; Kanada melalui Section 425.1 Criminal Code of Canada, dinyatakan bahwa whistleblower dilindungi dari pemberi pekerjaan yang memberikan hukuman disiplin, menurunkan pangkat, memecat atau melakukan tindakan apapun yang merugikan dari segi pekerjaan dengan tujuan untuk mencegah pekerja memberikan informasi kepada pemerintah atau badan pelaksanaan hukum atau untuk membalas pekerja yang memberikan informasi; Australia melalui Pasal 20 dan Pasal 21 Protected Disclosures Act 1994 yang merahasiakan identitas whistleblower, tidak ada pertanggungjawaban secara pidana dan perdata, perlindungan dari pencemaran nama baik, perlindungan dari pembalasan dan perlindungan kondisional apabila namanya dipublikasikan ke media; dan Inggris dalam Pasal 1 dan Pasal 2 Public Interest Disclosures Act 1998 diatur bahwa whistleblower tidak boleh dipecat dan dilindungi dari viktimisasi serta perlakuan yang merugikan.

Di Indonesia, pengaturan mengenai whistleblower dan justice collaborator diatur dalam berbagai peraturan perundang-undangan baik undang-undang, peraturan pemerintah, surat edaran Mahkamah Agung, peraturan Kapolri, peraturan bersama, surat edaran Menteri, dan lain sebagainya. ${ }^{2}$ Perkembangan ide justice collaborator

2 Dalam ketentuan hukum positif Indonesia, whistleblower dan justice collaborator selintas diatur dalam UU Nomor 13 Tahun 2006, UNCAC, UU Nomor 31 Tahun 1999 jo. UU Nomor 20 Tahun 2001, UU Nomor 8 Tahun 2010, UU Nomor 30 Tahun 2002, UU Nomor 5 Tahun 1997, UU Nomor 35 Tahun 2009, UU Nomor 26 Tahun 2000, UU Nomor 15 Tahun 2003, UU Nomor 5 Tahun 2009, UU Nomor 21 Tahun 2007, PP Nomor 2 Tahun 2002, PP Nomor 57 Tahun 2003, PP Nomor 24 Tahun 2003, PP Nomor 9 Tahun 2008, PP Nomor 99 Tahun 2012, Peraturan Kapolri Nopol 5 Tahun 2005, Peraturan Kapolri Nopol 3 Tahun 2008, Peraturan Bersama Kepala Kepolisian Negara Republik Indonesia, Komisi Pemberantasan Korupsi Republik Indonesia, Ketua Lembaga Perlindungan Saksi dan Korban Republik Indonesia Nomor: M.HH-11.HM.03.02.th. 2011 Nomor: PER-045/A/JA/12/2011, Nomor: 1 
Lilik Mulyadi: Perlindungan Hukum Whistleblower dan Justice Collaborator dalam Upaya Penanggulangan Organized Crime di Indonesia

sebenarnya bertitik tolak dari ketentuan Pasal 37 ayat (2) United Nations Convention Against Corruption (UNCAC) Tahun 2003 yang telah diratifikasi Indonesia melalui UU Nomor 7 Tahun 2006 tentang Pengesahan United Nations Convention Against Corruption (Konvensi Perserikatan Bangsa-Bangsa Anti Korupsi 2003) ditegaskan bahwa:

"Each State Party shall consider providing for the possibility, in appropriate cases, of mitigating punishment of an accused person who provides substantial cooperation in the investigation or prosecution of an offence established in accordance with this Convention". (Setiap negara peserta wajib mempertimbangkan kemungkinan, dalam kasus-kasus tertentu, mengurangi hukuman dari seorang pelaku yang memberikan kerja sama substansial dalam penyelidikan atau penuntutan suatu kejahatan yang ditetapkan berdasarkan Konvensi ini).

Kemudian dalam Pasal 37 ayat (3) UNCAC dikemukakan bahwa:

"Each State Party shall consider providing for the possibility, in accordance with fundamental principles of its domestic law, of granting immunity from prosecution to a person who provides substantial cooperation in the investigation or prosecution of an offence established in accordance with this Convention" (Setiap negara peserta wajib mempertimbangkan kemungkinan, sesuai dengan prinsip-prinsip dasar hukum nasionalnya untuk memberikan kekebalan dari penuntutan bagi orang yang memberikan kerja sama substansial dalam penyelidikan atau penuntutan (justice collaborator) suatu tindak pidana yang ditetapkan berdasarkan Konvensi ini).

Selanjutnya, dalam Surat Keputusan Bersama Lembaga Perlindungan Saksi dan Korban (LPSK), Kejaksaan Agung, Kepolisian RI, KPK dan Mahkamah Agung Nomor: M.HH-11.HM.03.02.th. 2011 Nomor: PER-045/A/JA/12/2011, Nomor: 1 Tahun 2011, Nomor: KEPB-02/01-55/12/2011, Nomor: 4 Tahun 2011 tentang Perlindungan bagi Pelapor, Saksi Pelapor dan Saksi Pelaku yang bekerjasama, justice collaborator adalah seorang saksi, yang juga merupakan pelaku, namun mau bekerja sama dengan penegak hukum dalam rangka membongkar suatu perkara bahkan mengembalikan aset hasil kejahatan korupsi apabila aset itu ada pada dirinya.

Hakikatnya, whistleblower dan justice collaborator dapat berperan besar untuk mengungkap praktik-praktik koruptif lembaga publik, pemerintahan maupun

Tahun 2011, Nomor: KEPB-02/01-55/12/2011 Nomor: 4 Tahun 2011 tentang Perlindungan bagi Pelapor, Saksi Pelapor dan Saksi Pelaku yang Bekerjasama, Surat Edaran Menteri Pendayagunaan Aparatur Negara dan Reformasi Birokrasi Republik Indonesia Nomor 8/M.PAN-RB/06/12 tanggal 29 Juni 2012, Surat Edaran Mahkamah Agung RI Nomor 4 Tahun 2011 tentang Perlakuan agi Pelapor Tindak Pidana (Whistleblower) dan Saksi Pelaku yang Bekerjasama (Justice Collaborators) di dalam Perkara Tindak Pidana Tertentu dan lain sebagainya. 
Lilik Mulyadi: Perlindungan Hukum Whistleblower dan Justice Collaborator dalam Upaya Penanggulangan Organized Crime di Indonesia

perusahaan swasta. Oleh karena itu, tanpa adanya sistem pelaporan dan perlindungan whistleblower dan justice collaborator maka partisipasi publik untuk membongkar dugaan tindak pidana menjadi rendah sehingga praktik penyimpangan, pelanggaran, maupun kejahatan semakin meningkat.

Hal ini dikemukakan oleh Abdul Haris Semendawai yang pada pokoknya menyatakan bahwa peran whistleblower di Indonesia perlu terus didorong, disosialisasikan, dan diterapkan, baik di perusahaan, lembaga pemerintah, dan institusi publik lain. Bagaimana peran whistleblower di Indonesia dibangun dan dikembangkan memang membutuhkan waktu dan sebuah proses. Namun, praktik pelaporan dan perlindungan terhadap whistleblower bukan tanpa tantangan. Di tengah minimnya perlindungan hukum Indonesia, seorang whistleblower dapat terancam karena laporan atau kesaksiannya atas dugaan pelanggaran dan kejahatan yang terjadi. Pihak-pihak yang merasa dirugikan kemungkinan besar akan memberikan perlawanan untuk mencegah whistleblower memberikan laporan atau kesaksian. Bahkan tak menutup kemungkinan mereka yang merasa dirugikan dapat mengancam dan melakukan pembalasan dendam. Untuk itu, agar praktik pelaporan dan pengungkapan fakta oleh whistleblower dapat berjalan lebih efektif, dibutuhkan perubahan pengaturan di dalam UU Nomor 13 Tahun 2006 tentang Perlindungan Saksi dan Korban. Selain itu, Surat Edaran Mahkamah Agung (SEMA) Nomor 4 Tahun 2011 penting untuk diterapkan oleh semua hakim dalam memutus perkara dan selalu dimonitor pelaksanaannya. ${ }^{3}$

Pada dasarnya, lahirnya undang-undang yang memfasilitasi justice collaborator dengan penegak hukum diperkenalkan pertama kali di Amerika Serikat tahun 1970an. Fasilitas tersebut tak lain untuk menghadapi para mafia, yang sejak lama telah menerapkan omerta (sumpah tutup mulut sekaligus merupakan hukum tertua dalam dunia Mafioso Sicilia). Untuk kejahatan terorisme, penggunaan justice collaborator dipraktikkan di Italia (1979), Portugal (1980), Irlandia Utara, Spanyol (1981), Perancis (1986) dan Jerman (1989) sedangkan untuk kejahatan narkoba diterapkan di Yunani (1970), Perancis, Luksemburg dan Jerman. Terminologi justice collaborator dipergunakan berbeda di negara-negara tersebut seperti "supergrasses" (Irlandia), "pentiti" atau "pentito" (Italia) yang berarti "mereka telah bertobat" atau disebut "callaboratore della giustizia".

Di Indonesia, praktik perlindungan whistleblower dan justice collabolator dilakukan terhadap Vincentius Amin Sutanto, Agus Condro Prayitno, Yohanes Waworuntu, Susno Duadji, dan Endin Wahyudin. ${ }^{4}$ Kemudian di negara asing,

3 Abdul Haris Semendawai (et.al.), Memahami Whistleblower, Jakarta: Lembaga Perlindungan Saksi dan Korban (LPSK), 2011, hlm. xiv-xv.

4 Vincentius Amin Sutanto, mantan financial controller di Asian Agri Group, melakukan pembobolan uang Asian Agri dengan membuat dua aplikasi transfer fiktif dari PT. Asian Agri Oils and Fats Ltd. ke Bank Fortis, Singapura 
Lilik Mulyadi: Perlindungan Hukum Whistleblower dan Justice Collaborator dalam Upaya Penanggulangan Organized Crime di Indonesia

misalnya pada Colen Rowey (Amerika Serikat), Jeffrey Wigand (Amerika Serikat), Shanmughan Manjunath (India), Yoichi Mitzuni (Jepang) ${ }^{5}$, dan sebagainya.

Lazimnya, praktik perlindungan tersebut diberikan kepada kejahatan terorganisasi (organized crime). Berdasarkan tipologi kejahatan, organized crime adalah kejahatan yang paling rumit dan sulit pengungkapannya. Dalam kejahatan ini dimungkinkan juga jenis kejahatan lain seperti white collar crime, corporate crime dan transnational crime serta international crime. Para pelaku organized crime tentunya adalah orang-orang yang mempunyai keahlian di bidangnya yang mampu mengorganisasi peran, motif dan tugas serta fungsinya masing-masing, baik sebelum kejahatan dilakukan hingga penghilangan jejak setelah kejahatan dilakukan. Jika dipandang dari jenis pelaku kejahatan, organized crime dapat juga digolongkan sebagai white collar crime. Di sisi lain, organized crime dalam hal penggunaan metode pelaksanaan kejahatannya juga dimungkinkan menggunakan sarana berupa korporasi-korporasi yang sengaja diorganisasi sedemikian rupa untuk melakukan kejahatan. Jika dipandang dari jenis sarananya, maka organized crime dapat juga digolongkan sebagai corporate crime. Selain itu terdapat juga organized crime yang dalam melakukan kejahatannya meliputi lintas batas negara sehingga juga tergolong sebagai transnational crime. Bahkan ada juga organized crime meliputi international crime karena jenis kejahatan yang diorganisasi oleh pelaku termasuk dalam kejahatan-kejahatan yang telah ditetapkan oleh konvensi internasional sebagai international crime.

Demikian kompleksnya dimensi kejahatan organized crime hingga dalam hal pendefinisiannya pun para ahli mengalami kesulitan. Pierre Hauck dan Sven Peterke menyatakan bahwa: ${ }^{6}$

"Kejahatan terorganisir dapat digunakan untuk merujuk pada jenis tertentu kegiatan kriminal yang rumit dan kompleks. Senjata, narkotika, dan perdagangan manusia sering dikaitkan dengan serangkaian enabling

dengan memalsukan tanda tangan dan kemudian memberi keterangan tentang penggelapan yang dilakukan oleh perusahaan tempatnya bekerja. Kemudian Agus Condro Prayitno dalam kasus dugaan suap Bank Indonesia (BI) kepada Hamka Yandu, Yohanes Waworuntu mengenai masalah Sistem Administrasi Badan Hukum (Sisminbakum) dan Endin Wahyudin tentang kasus yang melibatkan suap terhadap tiga hakim agung.

5 Colen Rowey adalah seorang agen khusus $\mathrm{FBI}$ yang mengungkapkan kelambanan $\mathrm{FBI}$ yang mungkin menyebabkan terjadinya serangan teroris pada tanggal 11 September 2001 di World Trade Center dan Pentagon. Jeffrey Wigand, seorang direksi di Bagian Riset dan Pengembangan (1988-1993) perusahaan rokok Brown and Williamson Tobacco Corporation, yang memberi laporan atau kesaksian atas praktik manipulasi kadar nikotin rokok yang diduga terjadi di perusahaan itu kemudian kisah ini diangkat ke layar lebar (1996) dengan judul film "The Insider" yang memenangkan Piala Oscar 1996. Shanmughan Manjunath, seorang manajer di perusahaan minyak milik negara India, yang mengungkapkan skema penjualan bensin tidak murni dan Yoichi Mitzutani, seorang presiden direktur perusahaan penyimpanan Nishinomiya Reizo di Jepang, yang melaporkan mengenai penipuan yang dilakukan oleh Snow Brand Food Co. telah melakukan pelabelan palsu.

6 Pierre Hauck dan Sven Peterke, "Kejahatan Terorganisir dan Kekerasan Geng dalam Hukum Nasional dan Internasional”, International Review of The Red Cross, Volume 92, Number 878, June 2010, hlm. 45. 
Lilik Mulyadi: Perlindungan Hukum Whistleblower dan Justice Collaborator dalam Upaya Penanggulangan Organized Crime di Indonesia

activities seperti (ancaman) kekerasan, korupsi, dan pencucian uang. Kejahatan terorganisasi dapat digunakan dalam arti organisasi kriminal seperti kartel narkotika Kolombia dan Meksiko, yakuza Jepang, triad Cina atau mafia Italia dan Amerika Serikat."

Kompleksitas dimensi organized crime, berimplikasi pada jarangnya pengaturan tentang kejahatan terorganisasi dalam hukum pidana nasional suatu negara. Sebagai contoh, dapat ditemukan pada hukum pidana India dalam Maharashtra Control of Organized Crime Act India Tahun 1999 yang mendefinisikan kejahatan terorganisasi sebagai: ${ }^{7}$

"Kegiatan yang melanggar hukum secara terus-menerus oleh seorang individu, secara sendiri atau bersama-sama, baik sebagai anggota sindikat kejahatan terorganisasi atau atas nama sindikat tersebut, dengan menggunakan kekerasan atau ancaman kekerasan atau intimidasi atau pemaksaan, atau cara lain yang melanggar hukum, dengan tujuan mendapatkan manfaat berupa uang, atau mendapatkan keuntungan ekonomi atau lainnya yang tidak semestinya untuk dirinya sendiri atau orang lain atau mempromosikan pemberontakan (insurgency)".

Meskipun cukup sulit untuk memberikan definisi organized crime dalam konteks ini, organized crime dapat didefinisikan sebagai suatu kejahatan dilakukan oleh lebih dari dua orang melalui sebuah persekongkolan atau pemufakatan bersama untuk bertindak jahat sesuai dengan peran dan tugas masing-masing (notabene telah terbagi) yang kemudian hasil dari kejahatan tersebut dibagi-bagi. Adapun pemufakatan dan persekongkolan yang dimaksud termasuk di dalamnya melakukan, membantu, turut serta, menyuruh, menganjurkan, memfasilitasi, konsultasi, dan lain-lain yang terkait dengan aktivitas manajerial dalam operasionalisasi kejahatan.

Berdasarkan latar belakang diatas, tulisan ini mengkaji lebih detail model ideal perlindungan hukum whistleblower dan justice collabolator dalam upaya penanggulangan organized crime di Indonesia untuk masa mendatang (ius constituendum). Diharapkan, nantinya ditemukan formulasi dan regulasi ideal bagi kebijakan legislasi untuk melakukan pembaharuan hukum pidana khusus dan hukum acara pidana untuk diterapkan pada praktik perlindungan hukum terhadap whistleblower dan justice collabolator yang terjadi di Indonesia mengacu pada model ideal tersebut.

\section{B. Orientasi Perlindungan terhadap Whistleblower dan Justice Collabolator dalam Upaya Penanggulangan Organized Crime di Indonesia}

7 SATP,"Maharashtra Control of Organised Crime Act Pasal (e)”,

<http://www.satp.org/satporgtp/countries/india/document/actandordinances/maharashtra1999.htm>, diunduh tanggal 25 Mei 2013. 
Lilik Mulyadi: Perlindungan Hukum Whistleblower dan Justice Collaborator dalam Upaya Penanggulangan Organized Crime di Indonesia

\section{Lembaga Perlindungan}

Persoalan krusial dan substansial lembaga perlindungan pada masa mendatang (ius constituendum) adalah dimensi tentang eksistensi lembaga yang kiranya paling ideal untuk menangani dan memberikan perlindungan terhadap seorang whistleblower maupun justice collaborator. Dimensi ini perlu mendapat perhatian khusus, karena berkorelasi dengan proses penanganan laporan agar dapat ditangani secara tepat, cepat, dan efektif. Seorang whistleblower maupun justice collaborator harus mendapat perlindungan serta jaminan keamanan atas informasi yang diberikannya.

Dikaji dari peraturan perundang-undangan saat ini seorang whistleblower maupun justice collaborator dapat melapor kepada Lembaga Perlindungan Saksi dan Korban (LPSK), Komisi Pemberantasan Tindak Pidana Korupsi (KPK), Komisi Yudisial, Ombudsman Republik Indonesia, Pusat Pelaporan dan Analisis Transaksi Keuangan, Komisi Kepolisian Nasional dan Komisi Kejaksaan. Permasalahan yang kemudian muncul dalam konteks ini yaitu banyaknya lembaga yang dapat menerima laporan dari seorang whistleblower maupun justice collaborator. Dari perspektif sistem peradilan pidana, dimensi ini berkorelasi dengan lembaga-lembaga yang berada di luar sistem peradilan pidana yang mempunyai legitimasi dalam memberikan keringanan hukuman terhadap seorang whistleblower maupun justice collaborator.

Kemudian dari perspektif banyaknya lembaga yang berwenang menangani laporan seorang whistleblower maupun justice collaborator, akan menimbulkan masalah tersendiri seperti konflik kewenangan antara aparat penegak hukum atau lembaga satu dengan lainnya. Misalnya, dalam pelaksanaan UU Nomor 13 Tahun 2006 terkait pemahaman atas fungsi, tugas dan kewenangan LPSK dalam konteks pemberian perlindungan terhadap seorang whistleblower maupun justice collaborator.

Pelaksanaan tugas tersebut potensial bersinggungan dengan kewenangan penegak hukum lain (kepolisian, kejaksaan dan KPK) khususnya terkait pelaksanaan Pasal 10 UU Nomor 13 Tahun 2006. Konsekuensi logisnya, diperlukan suatu penegasan atas kewenangan, fungsi dan tugas serta koordinasi antar lembaga untuk melakukan perlindungan terhadap whistleblower maupun justice collaborator sehingga diharapkan hubungan dan koordinasi antar lembaga tersebut tidak megalami kendala ketika dilakukan implementasi praktik dan pelaporan terhadap seorang whistleblower maupun justice collaborator.

Adanya sistem pengajuan permohonan perlindungan terlebih dahulu kepada LPSK yang kemudian dilanjutkan dengan proses penilaian, akan memakan waktu dan energi para whistleblower dan/atau justice collaborator sehingga birokrasi demikian akan menyulitkan mereka yang memiliki keterbatasan akses misalnya berada di daerah pelosok yang jauh dari Kantor LPSK di Jakarta. Hal ini tentu akan membuat pelayanan perlindungan mereka menjadi kurang efektif dan efisien. Oleh karena itu, 
Lilik Mulyadi: Perlindungan Hukum Whistleblower dan Justice Collaborator dalam Upaya Penanggulangan Organized Crime di Indonesia

apabila eksistensi LPSK tetap dipertahankan karena secara fungsional dibutuhkan sebagai salah satu sub-sistem peradilan pidana sebagaimana penegak hukum lain (untuk menguatkan LPSK kewenangan dalam reformulasi hukum acara pidana agar tidak terjadi tumpang tindih dengan penegak hukum dan menghilangkan anggapan saling intervensi), maka perlu didirikan kantor-kantor LPSK di daerah, bahkan bila perlu di setiap kabupaten dan kota. Sedangkan, apabila eksistensi LPSK yang notabene adalah ad hoc atau sementara, maka kantor-kantor perwakilan LPSK di daerah tersebut tidak diperlukan karena anggaran negara yang dikeluarkan akan besar sekali. Selain itu ditinjau dari perspektif asas peradilan sederhana, cepat dan biaya ringan, penggemukan institusi sistem peradilan pidana lambat laun akan menghambat proses penyelesaian perkara pidana, sehingga kewenangan perlindungan saksi, pelapor dan justice collaborator tersebut dilekatkan pada unit internal dari penegak hukum misalnya unit perlindungan khusus di kepolisian, kejaksaan maupun pengadilan.

Idealnya dari kajian perspektif perbandingan kelembagaan, dibuat peraturan tentang lembaga yang mengatur, menangani dan berwenang khusus terhadap whistleblower maupun justice collaborator secara tersendiri dan bersifat integral seperti di Amerika Serikat dengan The US Office of Special Counsel (OSC) sesuai dengan sistem peradilan pidana yang hendak dibangun. Konsekuensi logisnya adalah diperlukannya suatu pembaharuan sistem hukum termasuk ketentuan hukum acara pidana yang sesuai dengan jiwa, sistem, kultur masyarakat Indonesia yang berkorelasi dengan sistem peradilan pidana Indonesia pada khususnya.

\section{Konsep Pendekatan Keadilan Restoratif (Restorative Justice Approach)}

Konsep pendekatan keadilan restoratif ${ }^{8}$ (restorative justice approach) kiranya relatif

8 Keadilan restoratif (restorative justice), yang diperkenalkan pertama kali oleh Albert Eglash, diartikan sebagai suatu alternatif pendekatan restitutif terhadap pendekatan keadilan retributif dan keadilan rehabilitatif (J. Hudson dan Galaway, Restitution in Criminal Justice, Massachusetts, Lexington, USA, 1977, hlm. 95). Oleh karena itu, prinsip-prinsip umum pendekatan restoratif adalah prinsip penyelesaian yang adil (due process), perlindungan yang setara, hak-hak korban, proporsionalitas, praduga tak bersalah dan hak bantuan konsultasi atau penasihat hukum (Rufinus Hotmaulana Hutauruk, Penanggulangan Kejahatan Korporasi melalui Pendekatan Restoratif Suatu Terobosan Hukum, Jakarta: Sinar Grafika, 2013, hlm. 126-136). Pasal 1 angka 6 UU Nomor 11 Tahun 2012 menyebutkan keadilan restoratif adalah penyelesaian perkara tindak pidana dengan melibatkan pelaku, korban, keluarga pelaku/korban, dan pihak lain yang terkait untuk bersama-sama mencari penyelesaian yang adil dengan menekankan pemulihan kembali pada keadaan semula dan bukan pembalasan. Howard Zehr menyebutkan bahwa, "Restorative justice is touded as a long-overdue third model or a new 'lens' a way of hopping off the seesaw, of heading more consistently in a new direction while enrolling both liberal politicans who support the welfare model and conservatives who support the justice model" (Howard Zehr, "Retributive Justice, Restorative Justice, New Perspectives on Crime and Justice: Occasional Papers of the MCC Canada Victims Offender Ministeries Program the MCC", U.S. Office of Criminal Justice, No. 4, Canada Victim Offender Ministries Program, Ontario, 1985, hlm. 10) dan Tony Marshall menyebutkan, "Restorative justice is a process whereby all the parties with a stake in a particular offence together to resolve collectively how to deal with 
Lilik Mulyadi: Perlindungan Hukum Whistleblower dan Justice Collaborator dalam Upaya Penanggulangan Organized Crime di Indonesia

tepat untuk diterapkan pada perlindungan hukum whistleblower dan justice collaborator dalam upaya penanggulangan organized crime di Indonesia pada masa mendatang. Ada beberapa argumentasi yang dapat dikemukakan dalam hal ini mengenai mengapa konsep pendekatan keadilan restoratif yang dikedepankan, yaitu: ${ }^{9}$

a. Asas equality before the law dan asas non-impunity dalam hal penanganan perlindungan hukum terhadap whistleblower dan justice collaborator dalam upaya penanggulangan organized crime relatif tidak dapat diterapkan karena tindak pidana organized crime terlalu kompleks, multi dimensional dan melintasi batas negara, sehingga pengungkapannya mutlak memerlukan whistleblower dan justice collaborator. Konsekuensi logisnya, tidak semua orang harus diperlakukan sama karena terdapat aspek tertentu yang membedakan orang tersebut dengan orang lain. Perbedaan itu membuka ruang dan dimensi bahwa seseorang dapat saja tidak dijatuhi pidana asal bertanggung jawab atas perbuatannya dengan melakukan pemulihan keseimbangan seperti keadaan semula (restitutio in integrum) akibat perbuatan yang telah dilakukannya. Tegasnya, dalam hal ini diterapkan asas kesamaan hukum yang adil (equality before the justice);

b. Konsep pendekatan restorative justice berlandaskan pada asas ketidaksamaan sebagai keadilan. Kontribusi yang diberikan oleh justice collaborator dalam mengungkap kasus korupsi ini dijadikan dasar yang membedakannya dengan koruptor biasa, sehingga kontribusi justice collaborator ini menjadi dasar untuk menghindarkannya dari pemidanaan;

c. Pengungkapan kasus rumit dengan perlindungan hukum terhadap whistleblower dan justice collaborator dalam upaya penanggulangan organized crime melalui pendekatan keadilan restoratif (restorative justice approach) akan memberikan dorongan keberanian dalam mengungkapkan kebenaran serta perasaan tidak takut, sehingga diharapkan berdampak pada besarnya keinginan orang lain untuk menjadi seorang whistleblower dan justice collaborator;

d. Penjatuhan pidana terhadap whistleblower dan justice collaborator dalam perkara yang termasuk organized crime pada hakikatnya adalah untuk memanusiakan manusia agar menjadi orang yang baik. Hal tersebut sejalan

the aftermath of the offence and its implications for the future" (Tony Marshall, "Restorative Justice on Trial in Britain, in Restorative Justice on Trial: Pitfalls and Potentials of Victim-Offender Mediation-International Research Perspectives", dalam buku yang disusun oleh H. Messmer dan H.U. Otto Dordrecht (eds.), Boston: Kluwer Academic Publishers, 1992, hlm. 11).

9 Yutirsa Yunus, "Rekomendasi Kebijakan Perlindungan Hukum Justice Callaborator: Solusi Akselerasi Pelaporan Tindak Pidana Korupsi di Indonesia", Paper disampaikan dalam Konferensi Kebijakan Perencanaan Pembangunan Nasional 2013, hlm. 16. 
Lilik Mulyadi: Perlindungan Hukum Whistleblower dan Justice Collaborator dalam Upaya Penanggulangan Organized Crime di Indonesia

dengan eksistensi UU Nomor 12 Tahun 1995 tentang Pemasyarakatan yang menyatakan bahwa lembaga pemasyarakatan merupakan tempat untuk membuat narapidana menjadi orang yang baik. Filsafat pemidanaan dan penjatuhan pidana di Indonesia bukan berdasarkan filsafat retributif, melainkan filsafat integratif. Oleh karena itu, pendekatan keadilan restoratif harus diutamakan oleh Indonesia; dan

e. Konsep pendekatan restorative justice di satu sisi dengan perlindungan hukum whistleblower dan justice collaborator. Di sisi lainnya, adanya reward sekaligus tanggung jawab bagi whistleblower dan justice collaborator diharapkan dapat mengungkap perkara secara signifikan yang berdimensi organized crime. Dalam dimensi ini, memang diperlukan perlindungan khusus bagi whistleblower dan justice collaborator. Hal ini tiada lain karena para whistleblower dan justice collaborator tidak akan berani memberikan keterangan tentang apa yang dilihat dan dialami karena tekanan, intimidasi bahkan terancam keselamatan jiwanya. Perlindungan khusus ini penting karena organized crime tersebut menimbulkan masalah dan ancaman serius terhadap stabilitas ekonomi, perdagangan, ancaman dan ketertiban masyarakat yang meruntuhkan lembaga serta nilai-nilai demokrasi dan keadilan serta membahayakan pembangunan berkelanjutan dan supremasi hukum.

Pada dasarnya, konsep pendekatan restorative justice membuat seseorang berani untuk menjadi seorang whistleblower dan justice collaborator dalam perkara yang termasuk organized crime. Keputusan dan pendirian seseorang untuk menjadi seorang whistleblower dan justice collaborator perlu diapresiasi dengan baik sehingga membangun kesadaran dan polarisasi berpikir bahwa keputusan tersebut akan sangat berguna dan mempunyai jasa dalam rangka mengungkapkan perkara organized crime. Konsekuensinya, sanksi pidana yang akan dijatuhkan hakim kepada seorang whistleblower dan justice collaborator memiliki dimensi keadilan. Pemidanaan yang berdimensi keadilan tersebut, membawa pemidanaan seseorang sesuai asas pemasyarakatan sekaligus memanusiakan narapidana atau pelaku tindak pidana menjadi manusia yang baik.

\section{Syarat dan Jenis Perlindungan}

Syarat dan jenis perlindungan kepada whistleblower dan justice collaborator berorientasi pada ketentuan Pasal 37 ayat (3) Konvensi PBB Anti Korupsi 2003 yang diratifikasi Indonesia dengan UU Nomor 7 Tahun 2006. Ketentuan tersebut menentukan bahwa:

"Each State Party shall consider providing for the possibility, in accordance with fundamental principles of its domestic law, of granting immunity from prosecution to a person who provides substantial cooperation in the investigation or prosecution of an offence established in accordance with this 
Lilik Mulyadi: Perlindungan Hukum Whistleblower dan Justice Collaborator dalam Upaya Penanggulangan Organized Crime di Indonesia

Convention" (Setiap negara peserta wajib mempertimbangkan kemungkinan sesuai dengan prinsip-prinsip dasar hukum nasionalnya, untuk memberikan kekebalan dari penuntutan bagi orang yang memberikan kerja sama substansial dalam penyelidikan atau penuntutan suatu tindak pidana yang ditetapkan berdasarkan Konvensi ini).

Ide dasar perlindungan berupa imunitas terhadap justice collaborator tersebut identik dengan ketentuan Pasal 10 ayat (1) UU Nomor 13 Tahun 2006. Pemberian imunitas dapat dijadikan sebagai bargain position bagi para pelaku ketika memberikan informasi akurat dan berkualitas kepada aparat penegak hukum. Hal tersebut sesuai dengan ketentuan Pasal 32 Konvensi PBB Anti Korupsi 2003 yang mewajibkan untuk memberikan perlindungan. Pemberian perlindungan kepada justice collaborator diharapkan dapat mengungkap jaringan kasus organized crime sebagaimana termaktub dalam Pasal 24 Konvensi Palermo tentang Transnational Organize Crime tentang protection of witnesses atau perlindungan saksi bahwa:

a. Each State Party shall take appropriate measures within its means to provide effective protection from potential retaliation or intimidation for witnesses in criminal proceedings who gives testimony concerning offences covered by this Convention and, as appropriate, for their relatives and other persons close to them.

b. The measures envisaged in Paragraph 1 of this article may include, inter alia, without prejudice to the rights of the defendant, including the right of due process:

1) Establishing procedures for the physical protection of such persons, such as, to the extend necessary and feasible, relocating them and permitting, where appropriate, non disclosure of information concerning the identity and whereabouts of such persons;

2) Providing evidentiary rules to permit witness testimony to be given in a manner that ensures the safety of the witness, such as permitting testimony to be given through the use of communications technology such as video links or other adequate means.

c. States Parties shall consider entering into agreements or arrangements with other States for the relocation of persons referred to in Paragraph 1 of this article.

d. The provisions of this article shall also apply to victims insofar as they are witnesses.

Selanjutnya, konteks di atas memperlihatkan bahwa seorang whistleblower dan justice collaborator merupakan pelapor yang diduga melakukan tindak pidana atau pelaku dari tindak pidana yang dilaporkannya. Maka demikian, syarat untuk dapat dilindunginya seorang whistleblower dan justice collaborator adalah mengakui keterlibatannya dalam perkara organized crime, mau melakukan kerja sama secara 
Lilik Mulyadi: Perlindungan Hukum Whistleblower dan Justice Collaborator dalam Upaya Penanggulangan Organized Crime di Indonesia

integral, kooperatif dan partisipatif dengan aparat penegak hukum dalam mengungkapkan kasus tersebut, serta mau melakukan pengembalian terhadap kerugian yang ditimbulkan akibat tindak pidana organized crime tersebut. Kemudian dengan bertitik tolak kepada ide dan syarat perlindungan, selanjutnya jenis perlindungan yang mungkin dapat diperoleh seorang whistleblower dan justice collaborator adalah perlindungan terhadap tuntutan pidana dan/atau perdata dari laporannya, perlindungan terhadap tuntutan pidana dan/atau perdata atas kasus atau perkara yang telah dilaporkannya, dan perlindungan dari tuntutan pidana dan/atau perdata atas kasus yang lain.

\section{Model Ideal Perlindungan Hukum terhadap Whistleblower dan Justice Collabolator dalam Upaya Penanggulangan Organized Crime di Indonesia p}

1. Model Hak-hak Prosedural atau Model Partisipasi Langsung atau Aktif (The Procedural Rights Model/Partie Civile Model/Civil Action System)

Model ini memungkinkan peran aktif saksi korban/pelapor dalam proses peradilan pidana seperti membantu jaksa/penuntut umum, dilibatkan dalam setiap tingkat pemeriksaan perkara, wajib didengar pendapatnya apabila terpidana dilepas bersyarat, memberi pertimbangan dalam menentukan pidana (victim opinion statement) dan sebagainya. ${ }^{10}$ Adanya keterlibatan saksi korban/pelapor mempunyai segi positif dalam penegakan hukum seperti memenuhi semangat pembalasan saksi korban/pelapor serta meningkatkan arus informasi kepada hakim. Ada juga segi negatif karena partisipasi aktif saksi korban/pelapor dalam pelaksanaan proses peradilan pidana yaitu dapat menyebabkan konflik antara kepentingan umum di bawah kepentingan pribadi saksi korban/pelapor yang dapat memicu dendam baru yang menjurus pada secondary victimization. Pada hakikatnya, negara-negara Anglo Saxon yang sistem peradilan pidananya dibangun atas dasar adversary or battle model, model ini akan menimbulkan kesulitan untuk melibatkan peranan pihak ketiga (korban). Sebaliknya, dalam sistem Eropa Kontinental yang memberlakukan sistem Inquisitur yang lebih terbuka kemungkinan untuk memberikan ruang gerak kepada kontribusi korban selama persidangan karena persidangan bukan merupakan legal

10 Korban kejahatan dipergunakan dalam beberapa terminologi dikaji dari perspektif ilmu kriminologi, viktimologi dan hukum positif Indonesia (ius constitutum) sesuai sistem peradilan pidana Indonesia yaitu sebagai pelapor (Pasal 108 Kitab Undang-undang Hukum Acara Pidana (KUHAP), Pasal 32-34 Perpu Nomor 1 Tahun 2002 jo. UU Nomor 15 Tahun 2003, Pasal 83-87 UU Nomor 8 Tahun 2010), pengadu (Pasal 72 KUHAP), saksi korban (Pasal 160 KUHAP), pihak ketiga yang berkepentingan (Pasal 80, 81 KUHAP), pihak ketiga yang dirugikan (Pasal 98, 99 KUHAP), dan perseorangan, masyarakat dan negara (Pasal 18, 41, 42 UU Nomor 31 Tahun 1999 jo. UU Nomor 20 Tahun 2001). Pada hakikatnya, secara konseptual, korban kejahatan tidak diakui eksistensinya sebagai pihak yang dirugikan karena kejahatan dalam perspektif hukum pidana sehingga korban bukan merupakan pihak/bagian dari sistem peradilan pidana. Konsekuensi logisnya, ada implikasi dalam sistem peradilan pidana yaitu tidak ada korelasi yang jelas antara korban, pelanggar hukum pidana (tersangka, terdakwa, terpidana), polisi dan jaksa penuntut umum. 
Lilik Mulyadi: Perlindungan Hukum Whistleblower dan Justice Collaborator dalam Upaya Penanggulangan Organized Crime di Indonesia

contest antara jaksa dan pengacara/pelaku. ${ }^{11}$

\section{Model Pelayanan atau Model Partisipasi secara Tidak Langsung atau Model Pasif (The Services Model)}

Dimensi ini menekankan pada pemberian ganti kerugian dalam bentuk kompensasi, restitusi dan upaya pengambilan kondisi korban yang mengalami trauma, rasa takut dan tertekan akibat kejahatan. ${ }^{12}$ Penekanan model ini diletakkan pada perlu diciptakannya standar baku bagi pembinaan korban kejahatan (saksi korban/pelapor) yang dapat digunakan oleh polisi. Contoh pembinaan di sini yakni dalam bentuk pedoman sebagai notifikasi kepada korban atau kejaksaan dalam rangka penanganan perkaranya, pemberian kompensasi sebagai sanksi pidana yang bersifat restitutif dan dampak pernyataan-pernyataan saksi korban sebelum pidana dijatuhkan. Pendekatan ini melihat korban kejahatan sebagai sasaran khusus untuk dilayani oleh polisi dan para penegak hukum lain.

Keuntungan model ini adalah bahwa model ini dapat digunakan sebagai sarana pengembalian dari yang dinamakan sebagai integrity of the system of institutionalized trust dalam kerangka perspektif komunal. Saksi dan/atau korban (saksi korban/pelapor) akan merasa dijamin kepentingannya dalam suasana tertib sosial yang adil sehingga tercipta suasana tertib, terkendali, dan saling mempercayai. Keuntungan lainnya dari model ini adalah dapat menghemat biaya, karena dengan bantuan pedoman yang baku, peradilan pidana dapat mempertimbangkan kerugiankerugian yang diderita oleh saksi dan atau korban dalam rangka menentukan kompensasi bagi korban.

Kelemahan model ini antara lain: kewajiban-kewajiban yang dibebankan kepada polisi, jaksa dan pengadilan untuk selalu melakukan tindakan-tindakan tertentu kepada saksi dan atau korban, dianggap membebani aparat penegak hukum karena semuanya didasarkan atas sarana dan prasarana yang sama. Efisiensi juga akan terganggu sebab pekerjaan yang bersifat profesional tidak mungkin digabungkan dengan urusan-urusan yang dianggap dapat mengganggu efisiensi. Model ini menentukan standar baku tentang pelayanan terhadap saksi korban yang dilakukan oleh polisi, jaksa, dan hakim, misalnya pelayanan kesehatan, pendampingan, pemberian kompensasi, ganti rugi, serta restitusi. Masalah yang timbul dalam model ini adalah untuk memantau apakah pelayanan itu benar-benar diterima oleh saksi dan korban. ${ }^{13}$

11 Lilik Mulyadi, Bunga Rampai Hukum Pidana Umum dan Khusus Indonesia dalam Teori dan Praktik, Bandung: PT. Alumni, 2012, hlm. 211.

12 Ibid.

13 Imam Turmudhi, "Perlindungan Hukum terhadap Whistleblower Kasus Korupsi berdasarkan Undang-Undang Nomor 13 Tahun 2006 tentang Perlindungan Saksi dan Korban (Studi Kasus Susno Duadji)", Jakarta: Program Studi Pasca Sarjana Kekhususan Kejahatan Ekonomi dan Anti Korupsi Fakultas Hukum Universitas Indonesia, 2011, hIm. 51-52. 
Lilik Mulyadi: Perlindungan Hukum Whistleblower dan Justice Collaborator dalam Upaya Penanggulangan Organized Crime di Indonesia

\section{Model Persuasif/Partisipatif}

Model persuasif/partisipatif merupakan perlindungan terhadap whistleblower dan justice collaborator yang bersifat menyeluruh yang melibatkan komponen sistem peradilan pidana yaitu kepolisian, kejaksaan, pengadilan, lembaga pemasyarakatan/pemasyarakatan, dan KPK untuk perkara korupsi. Tugas dan kewenangan dari kepolisian adalah sebagai lembaga penyidikan terhadap perkara pidana umum dan pidana khusus. Lembaga kejaksaan merupakan lembaga yang melakukan penuntutan terhadap perkara pidana umum dan pidana khusus yang dilimpahkan oleh lembaga kepolisian. KPK merupakan lembaga yang berwenang melakukan penyidikan dan sekaligus penuntutan terhadap perkara tindak pidana korupsi yang bersifat extraordinary crime ke pengadilan tindak pidana korupsi. Berikutnya lembaga pengadilan yang mempunyai tugas dan kewenangan untuk memeriksa, mengadili, dan memutus perkara perdata, pidana umum, dan pidana khusus yang diajukan kepada KPK. Lembaga pemasyarakatan/pemasyarakatan merupakan lembaga pelaksana pidana dengan tugas dan wewenang sebagai tempat pembinaan narapidana berdasarkan sistem pemasyarakatan.

Model persuasif/partisipatif sesuai sistem peradilan pidana dalam arti sempit ini terlihat dari bagan 1 berikut ini.

\section{Bagan 1:}

Model Persuasif/Partisipatif sesuai Sistem Peradilan Pidana dalam Arti Sempit

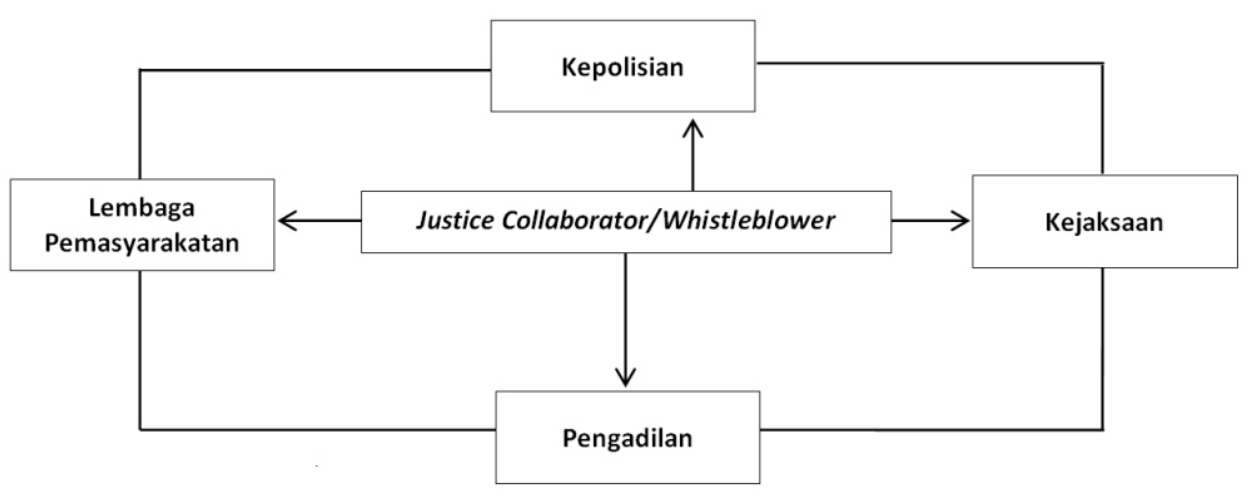

Model ini menimbulkan permasalahan terkait dengan eksistensi LPSK. Apabila eksistensi LPSK sebagaimana diatur dalam UU Nomor 13 Tahun 2006 tetap dipertahankan atau LPSK dimodifikasi dengan memperluas kewenangannya, maka 
seharusnya LPSK dimasukkan dalam komponen sistem peradilan pidana yang diperluas dalam KUHAP masa mendatang. Hal tersebut juga berlaku apabila ingin membangun lembaga baru bersifat independen dan mandiri yang bertugas untuk menangani secara khusus kasus whistleblower dan justice collaborator sebagaimana dikenal di Amerika Serikat, Jerman, Belanda, dan negara-negara lain. Model persuasif atau partisipatif sesuai sistem peradilan pidana dalam arti luas terlihat dari model bagan 2 berikut ini.

\section{Bagan 2:}

\section{Model Persuasif/Partisipatif sesuai Sistem Peradilan Pidana dalam Arti Luas}



Model persuasif/partisipatif, baik sesuai dengan sistem peradilan pidana dalam arti sempit maupun arti luas, bersifat integral yang antar komponen-komponen tersebut saling berkorelasi satu dengan lainnya. Apabila seorang whistleblower dan justice collaborator melapor kepada satu lembaga saja, maka keseluruhan komponen lembaga tersebut akan melindungi. Aspek positif dapat dikedepankan dalam dimensi ini sehingga relatif dapat menghindari kriminalisasi whistleblower dan justice collaborator. Model perlindungan persuasif/partisipatif ini akan memberi rasa aman, menghindarkan rasa takut terhadap tuntutan pidana dan/atau perdata serta mempunyai dimensi kepastian hukum (rechtszekerheid) kepada whistleblower dan justice collaborator.

\section{Model Perlindungan Komprehensif}

Model perlindungan komprehensif ini direkomendasikan oleh Yutirsa Yunus. Perlindungan justice collaborator harus dilakukan secara komprehensif atau 
Lilik Mulyadi: Perlindungan Hukum Whistleblower dan Justice Collaborator dalam Upaya Penanggulangan Organized Crime di Indonesia

menyeluruh mulai dari: (1) tahap pemberian laporan oleh justice collaborator; (2) tahap penindaklanjutan laporan yang terdiri atas penyelidikan, penyidikan, hingga pengadilan; dan (3) tahap putusan oleh pengadilan atas kasus korupsi yang dilaporkan tersebut. Model ini dapat dilihat dalam bagan 3 berikut ini.

\section{Bagan 3:}

Perlindungan Komprehensif bagi Justice Collaborator
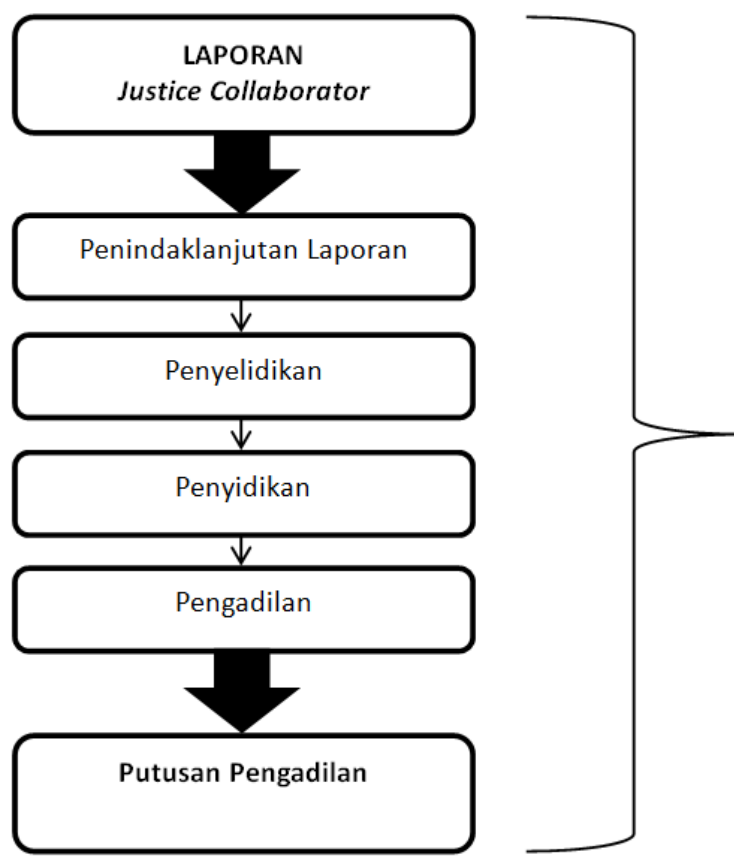

Perlindungan

Komprehensif

Perlindungan komprehensif ini dimaksudkan agar justice collaborator dituntut oleh pihak-pihak yang merasa dirugikan atas laporannya. Namun, tuntutan balik tersebut justru memberikan dampak negatif terhadap upaya pemberantasan korupsi, sehingga bagi justice collaborator putusan pengadilan yang dijatuhkan bersifat tetap (inkracht) atas kasus yang dilaporkannya tersebut. ${ }^{14}$

\section{Model Penjatuhan Pidana Bersyarat}

Hakikat model penjatuhan pidana bersyarat adalah mengelaborasi SEMA RI Nomor 4 Tahun 2011 dan ketentuan Pasal 37 ayat (2) UNCAC/Konvensi PBB Anti Korupsi 2003.

14 Yutirsa Yunus, Op.cit., hlm. 19. 
Seorang whistleblower merupakan pihak yang mengetahui dan melaporkan tindak pidana tertentu dan bukan salah satu dari pelaku kejahatan yang dilaporkannya. Kemudian terhadap saksi pelaku yang bekerja sama (justice collaborator), pelaku merupakan salah satu pelaku tindak pidana tertentu, mengakui kejahatan yang dilakukannya, bukan sebagai pelaku utama dalam kejahatan tersebut serta memberikan keterangan sebagai saksi dalam proses peradilan. Jaksa penuntut umum dalam tuntutan pidananya menyatakan yang bersangkutan telah memberikan keterangan dan bukti-bukti yang sangat signifikan sehingga penyidik dan/atau penuntut umum dapat mengungkap tindak pidana secara efektif, mengungkap pelaku-pelaku lainnya yang mempunyai peran lebih besar dan/atau mengembalikan aset-aset/hasil suatu tindak pidana. Atas bantuan tersebut, makajustice collaborator dapat dijatuhkan pidana bersayarat khusus dan/atau pidana penjara yang paling ringan di antara terdakwa lainnya yang terbukti bersalah dalam perkara tersebut. Dalam pemberian perlakuan khusus berupa keringanan pidana, hakim wajib mempertimbangkan keadilan masyarakat.

Hakikat model ini sesuai dengan ketentuan Pasal 37 ayat (2) UNCAC/Konvensi PBB Anti Korupsi 2003 yang berbunyi, "Each State Party shall consider providing for the possibility, in appropriate cases, of mitigating punishment of an accused person who provides substantial cooperation in the investigation or prosecution of an offence established in accordance with this Convention" (Setiap negara peserta wajib mempertimbangkan kemungkinan dalam kasus-kasus tertentu, memberi keringanan hukuman bagi seorang pelaku yang memberikan kerja sama substansial dalam penyelidikan atau penuntutan suatu kejahatan yang ditetapkan dalam Konvensi ini). Dalam praktiknya, model penjatuhan pidana bersyarat ini telah dilakukan oleh Mahkamah Agung RI melalui Putusan Nomor 920K/Pid.Sus/2013 terhadap terdakwa Thomas Claudius Ali Junaidi dengan ratio decidendi. Putusan Mahkamah Agung tersebut membenarkan alasan kasasi terdakwa sebagai justice collaborator, kemudian Mahkamah Agung membatalkan putusan pengadilan tinggi terkait, mengadili sendiri dengan menjatuhkan pidana kepada terdakwa selama 1 tahun dengan ketentuan pidana tersebut tidak perlu dijalani kecuali di kemudian hari terdakwa melakukan tindak pidana sebelum masa percobaan selama 2 tahun berakhir. Putusan Mahkamah Agung ini menerobos ketentuan pidana minimal selama 5 tahun sesuai ketentuan Pasal 114 ayat (1) UU Nomor 35 Tahun 2009 yang didakwakan kepada terdakwa.

\section{Model Perlindungan melalui Teleconference}

Salah satu bentuk perlindungan terhadap whistleblower dan justice collaborator yang merasa terancam jiwanya ketika dilakukan pemeriksaan di persidangan khususnya dalam penanganan perkara organized crime adalah melalui pemeriksaan teleconference. Pemeriksaan demikian dalam hukum positif Indonesia sebenarnya 
Lilik Mulyadi: Perlindungan Hukum Whistleblower dan Justice Collaborator dalam Upaya Penanggulangan Organized Crime di Indonesia

belum diatur, namun pada praktiknya telah dikenal dan dilakukan. Pada awalnya, persidangan menggunakan media teleconference ini mengundang perdebatan panjang. Ada yang menyetujui, namun tak sedikit pula yang menentang. Apabila dilihat dalam praktik dunia peradilan di Indonesia, media teleconference pernah digunakan dalam persidangan Rahardi Ramelan, dalam Pengadilan HAM Ad Hoc, perkara Abu Bakar Ba'asyir dan kasus Bom Bali dengan terdakwa Ali Gufron alias Muhklas (teleconference kesaksian Wan Min bin Wan Mat dari Malaysia). Teleconference sebagai bentuk kemajuan teknologi dalam hukum acara pidana dapat dijadikan salah satu cara untuk mendapatkan kebenaran material sehingga sangat memungkinkan dan rasional untuk dipergunakan dalam pemeriksaan di persidangan terhadap whistleblower dan justice collaborator dalam upaya penanggulangan organized crime di Indonesia pada masa mendatang. Urgensi, eksistensi dan relevansi adanya media teleconference ini diakui oleh M. Mohammad Saleh dalam pernyataannya sebagai berikut:

"Pada tahun 2002 ketika saya menjabat sebagai Ketua Pengadilan Negeri/Niaga/HAM Jakarta Pusat dalam memberikan perlindungan pada whistleblower dan justice collaborator yaitu pada saat persidangan Abu Bakar Ba'asyir dengan dakwaan melakukan tindak pidana makar. Pemeriksaan saksi-saksi yang berada di Singapura dan Malaysia dengan melalui teleconference saat itu belum diundangkan Undang-Undang Terorisme dan Undang-Undang Perlindungan Saksi dan Korban. Saat itu, belum ada undang-undang yang mengakomodasi pembuktian melalui teleconference. Perkembangan teknologi memang lebih cepat dibandingkan dengan perkembangan hukum, oleh karena itu demi mencari kebenaran materiil mendengarkan keterangan saksi-saksi yang berada di Singapura dan Malaysia terutama mereka yang ikut kegiatan yang dilakukan oleh Abu Bakar Ba'asyir di Malaysia dan Singapura pada saat itu (justice collaborator). Teleconference tersebut cukup memberikan gambaran bagi majelis tentang kegiatan Abu Bakar Ba'asyir di kedua negara itu". ${ }^{15}$

\section{Penutup}

Model ideal perlindungan hukum bagi whistleblower dan justice collaborator dalam upaya penanggulangan organized crime di Indonesia pada masa mendatang hendaknya berorientasi pada: model hak-hak prosedural atau partisipasi langsung

15 Mohammad Saleh, "Keynote Speech Wakil Ketua Mahkamah Agung Bidang Yudisial dalam Rapat Koordinasi antara LPSK dengan Unsur Aparat Penegak Hukum dalam Proses Peradilan Pidana dengan Tema 'Membangun Sistem Perlindungan dan Pemberian Penghargaan kepada Justice Collaborator (Saksi Pelaku yang Bekerjasama) pada Tindak Pidana Terorganisasi'”, Majalah Varia Peradilan, Tahun XXVII, No. 333, Agustus 2013, hlm. 8. 
Lilik Mulyadi: Perlindungan Hukum Whistleblower dan Justice Collaborator dalam Upaya Penanggulangan Organized Crime di Indonesia

atau aktif (the procedural rights model/partie civile model/civil action system); model pelayanan atau model partisipasi tidak langsung atau model pasif (the service model); model persuasif atau partisipasi, model perlindungan komprehensif; model penjatuhan pidana bersyarat dan model perlindungan melalui teleconference.

Perlu dipikirkan secara lebih mendalam mengenai opsi mempertahankan LPSK sesuai status quo atau membentuk LPSK baru dengan kewenangan yang diperluas atau lembaga baru bersifat mandiri dan independen yang mengatur secara khusus tentang whistleblower dan justice collaborator sebagaimana dikenal di Amerika Serikat, Afrika Selatan, Belanda, Jerman, Albania dan sebagainya. Selain itu, penting dibuat regulasi baru sebagai penyempurnaan dari UU Nomor 13 Tahun 2006 dan hukum positif Indonesia lainnya yang mengatur mengenai whistleblower dan justice collaborator sehingga perlindungan tersebut bersifat lebih lengkap, memadai, dan komprehensif. Pertimbangan yang mendalam dari berbagai sudut pandang mengenai perlu atau tidaknya dilakukan penuntutan atau penjatuhan pidana ringan berupa pidana percobaan terhadap whistleblower dan justice collaborator, khususnya dalam upaya penanggulangan organized crime sangat diperlukan.

\section{Daftar Pustaka}

\section{Buku}

Abdul Haris Semendawai (et.al.), Memahami Whistleblower, Lembaga Perlindungan Saksi dan Korban (LPSK), Jakarta, 2011.

Hudson, J. dan Galaway, Restitution in Criminal Justice, Lexington, Massachusetts, USA, 1977.

\section{Dokumen Lain}

Hauck, Pierre dan Sven Peterke, "Kejahatan Terorganisir dan Kekerasan Geng dalam Hukum Nasional dan Internasional", International Review of The Red Cross, Volume 92, Number 878, June 2010.

Imam Turmudhi, "Perlindungan Hukum Terhadap Whistleblower Kasus Korupsi berdasarkan Undang-Undang Nomor 13 Tahun 2006 tentang Perlindungan Saksi dan Korban (Studi Kasus Susno Djuadji)", Program Studi Pasca Sarjana Kekhususan Kejahatan Ekonomi dan Anti Korupsi, Jakarta, Juli 2011.

Mohammad Saleh, "Keynote Speech Wakil Ketua Mahkamah Agung Bidang Yudisial dalam Rapat Koordinasi antara LPSK dengan Unsur Aparat Penegak Hukum dalam Proses Peradilan Pidana dengan Tema 'Membangun Sistem Perlindungan dan Pemberian Penghargaan Kepada Justice Collaborator (Saksi Pelaku yang 
Lilik Mulyadi: Perlindungan Hukum Whistleblower dan Justice Collaborator dalam Upaya Penanggulangan Organized Crime di Indonesia

Bekerjasama) pada Tindak Pidana Terorganisasi'", Majalah Varia Peradilan, Tahun XXVII, No. 333, Agustus 2013.

SATP, "Maharashtra Control of Organised Crime Act (Pasal 2 (e))", <http://www.satp.org/satporgtp/countries/india/document/actandordinances /maharashtra1999.htm>, diunduh tanggal 25 Mei 2013.

Yutirsa Yunus, "Rekomendasi Kebijakan Perlindungan Hukum Justice Callaborator: Solusi Akselerasi Pelaporan Tindak Pidana Korupsi di Indonesia", Paper disampaikan dalam Konferensi Kebijakan Perencanaan Pembangunan Nasional 2013. 